\title{
ANALYSIS OF PHYSICOCHEMICAL, BIOCHEMICAL, AND ANTIBACTERIAL PROPERTIES OF INDIAN HONEY SAMPLES WITH SPECIAL REFERENCE TO THEIR NON-CONFORMITY
}

\author{
J.B. KaVAPURAYiL ${ }^{\mathrm{a}}$, S. Karalam ${ }^{\mathrm{b}}$ and R.P. ChANDRAN ${ }^{\mathrm{a} *}$ \\ ${ }^{a}$ Department of Biotechnology and Research, K.V.M. College of Engineering and Information Technology, \\ Kokkothamangalam P. O. Cherthala, 688583. Kerala State. India \\ ${ }^{\mathrm{b}}$ Research \& Development, Oushadhi, The Pharmaceutical Corporation (I.M.) Kerala Ltd., Kutannellur, P.O. \\ Thrissur, 680014. Kerala State. India
}

(Received: 3 February 2011; accepted: 13 November 2013)

\begin{abstract}
Honey is the natural sweet substance produced by bees from the nectar or secretions of plants or from excretions of plant-sucking insects, which the bees collect, transform by combining with specific substances of their own, deposit, dehydrate, store, and leave in honeycombs to ripen and mature. The physical properties of honey make it versatile and applicable to several industries. High consumer demand for honey consequently leads to widespread adulteration. In the present study, fifteen honey samples were collected from various parts of Kerala, India and classified into three categories: market samples, raw/wild samples, and industrial samples. The samples were then analysed for the following parameters: organoleptic features, physicochemical properties, biochemical characteristics, and microbiological state. The values obtained for physicochemical and biochemical analysis were compared to Standard values provided by the Bureau of Indian Standards. It was found that no honey ideally conformed to all parameter standards. Some samples clearly indicated conditions of improper handling. All honey samples showed significant polyphenol content. Although honey samples showed increased microbial growth upon dilution, they were also found to have effective antimicrobial properties. Significant links between moisture content, yeast count, and non-conformity in honey were determined, which highlights the necessity of proper storage conditions.
\end{abstract}

Keywords: honey analysis, adulteration, yeast, fermentation, antimicrobial properties

Honey is defined as the natural sweet substance produced by honeybees from the nectar of blossoms or from the secretion of living parts of plants or excretions of plant-sucking insects living on parts of plants, which honey bees collect, transform and combine with specific substances of their own, store and leave in honey combs to ripen and mature (CODEX Alimentarius Commission, 2001; Tсhoumboue et al., 2007).

Honey has several important qualities in addition to composition and taste. Hygroscopicity is a property of honey that describes the ability of honey to absorb and hold moisture from the environment. During processing or storage however, the same hygroscopicity can become problematic, causing difficulties in preservation and storage due to excess water content. Normal honey with water content of $18.8 \%$ or less will absorb moisture from air of a relative humidity of above $60 \%$. The colour of liquid honey varies from clear and colourless (like water) to dark amber or black. The various honey colours are basically of all shades of yellow, amber; like different dilutions or concentrations of caramelized sugar, which has been used traditionally as a colour standard. Colour varies with botanical origin, age, and storage conditions, but transparency or clarity depends on the amount of suspended particles such as pollen. Once crystallized, honey turns lighter in colour, because the glucose crystals are

\footnotetext{
* To whom correspondence should be addressed.

Phone: 91-0478 2811080; fax: 91-0478 2811707; e-mail: drpratapchandran@yahoo.co.in
} 
white. Honey crystallization results from the formation of monohydrate glucose crystals, which vary in number, shape, dimension, and quality with the honey composition and storage conditions. The lower the water and the higher the glucose content of honey, the faster the crystallization (OLAITAN et al., 2007). Honey contains a variety of phytochemicals that may serve as sources of dietary antioxidants (Efem, 1988; Gheldof \& Engeseth, 2002). The amount and type of these antioxidant compounds depend largely upon the floral source variety of the honey (GHELDOF et al., 2002).

Microbes found in honey are usually yeast and spore forming bacteria, those that indicate the sanitary or commercial quality of honey, and those that under certain conditions could cause human illness. The primary source of microbial contamination in honey is likely to include pollen, the digestive tracts of honeybees, dust, earth, and nectar, sources that are difficult to control. Some other sources of contamination include air, food handlers, cross contamination, equipments, and buildings. Secondary sources of contamination can be controlled by good manufacturing practices (KAČANIOVÁ et al., 2009). Total plate counts from honey can vary from zeros to tens to thousand for no apparent reason. Although yeast counts in many honey samples are below 100 colony-forming units per gram $\left(\mathrm{CFU} \mathrm{g}^{-1}\right)$, yeasts can grow in honey to very high numbers (SNOwDON \& CLIVER, 1996).

Honey is a supersaturated solution of sugars, up to 75 to $80 \%$ (depending on honey types) of it being a mixture of fructose and glucose (Olaitan et al., 2007). The strong interaction of these sugar molecules will leave very few of the water molecules available for microorganisms. The predominant acid found in honey is gluconic acid. Its presence in all types of honey originates from the activity of glucose oxidase. This enzyme causes the production of hydrogen peroxide, which is of antimicrobial efficacy (MALIKA et al., 2005).

\section{Materials and methods}

A series of tests were performed on the honey samples in order to determine the level of purity as well as the factors affecting the quality of honey.

\subsection{Honey samples}

Samples were collected and divided into three categories: market (available for consumer purchase in supermarkets in Kerala), raw (obtained from beekeepers, herbal medicine shops, and forest departments in Kerala), and industrial samples (procured from pharmaceutical industries in Kerala for use in medicine manufacture).

A total of 15 samples were collected and labelled as follows:

(i) Market honey samples: $M_{1}, M_{2}, M_{3}, M_{4}, M_{5}, M_{6}$

(ii) Raw/wild honey samples: $\mathrm{R}_{1}, \mathrm{R}_{2}, \mathrm{R}_{3}, \mathrm{R}_{4}, \mathrm{R}_{5}, \mathrm{R}_{6}$

(iii) Industrial honey samples: $\mathrm{I}_{1}, \mathrm{I}_{2}, \mathrm{I}_{3}$

\subsection{Preparation of honey samples}

Honey samples were stored airtight at $25^{\circ} \mathrm{C}$.

\subsection{Organoleptic analysis}

The colour, taste, and smell of the honey samples were tested by free choice profile method according to VIT and co-workers (2011). 


\subsection{Physicochemical analysis}

The methods were based on protocols of A.O.A.C. (1984); Bureau of Indian STANDARD SPECifications (BIS) FOR ExTRACTED Honey (2002).

The honey samples were tested for the following parameters:

(i) Specific gravity was determined using pycnometer at $25{ }^{\circ} \mathrm{C}$;

(ii) Moisture percentage was calculated using Abbe's refractometer;

(iii) Acidity: by titrating honey solution against $\mathrm{NaOH}(0.5 \mathrm{~N})$ and phenolphthalein;

(iv) Ash percentage: by burning honey samples at $600{ }^{\circ} \mathrm{C}$ in the muffle furnace;

(v) Reducing sugar content: by titrating honey stock solution against modified Fehling A and B solutions using methylene blue indicator;

(vi) Sucrose content is assayed using the same procedure as (v) on inverted honey solution prepared using hydrochloric acid.

\subsection{Biochemical analysis}

1.5.1. Determination of non-conformity. The honey samples were checked for nonconformity using the following tests:

Fiehe's test (Preliminary):

The ether extracts of honey were prepared by grinding honey and diethyl ether using mortar and pestle. The production of cherry red colour instantly on adding freshly prepared resorcinol to the ether extract of honey indicated a positive reaction, presence of hydroxymethyl furfural. Faint pink colour disappearing after a short time or yellow to salmon pink colour indicated a negative reaction.

5-Hydroxymethyl furfural (HMF) assay:

Two test tubes containing $2 \mathrm{ml}$ of test sample of $20 \%(\mathrm{w} / \mathrm{v})$ honey (with one tube acting as the blank) were made to react with $5 \mathrm{ml}$ of $p$-toluidine solution each. In the blank tube, $1 \mathrm{ml}$ of water was pipetted and into the other $1 \mathrm{ml}$ of barbituric acid solution and both mixtures was shaken. The absorbance of sample was read against blank at $550 \mathrm{~nm}$. The result was expressed in $\mathrm{mg} \mathrm{HMF} / \mathrm{kg}$ honey after calculation using the formula

$$
\mathrm{mg} / 100 \mathrm{~g} \mathrm{HMF}=(\text { Absorbance } \times 19.2) /(\text { Optical path length })
$$

1.5.2. Estimation of total polyphenols. A $0.5 \mathrm{ml}$ aliquot of honey solution was added to $2.5 \mathrm{ml}$ of $0.2 \mathrm{~N}$ Folin-Ciocalteu reagent and mixed for $5 \mathrm{~min}$, followed by the addition of 2 $\mathrm{ml}$ of $75 \mathrm{~g} \mathrm{l}^{-1}$ sodium carbonate $\left(\mathrm{Na}_{2} \mathrm{CO}_{3}\right)$. After incubation at room temperature for $2 \mathrm{~h}$, the absorbance of the reaction mixture was measured at $760 \mathrm{~nm}$ against a blank. The total phenol content was expressed as mg of gallic acid equivalents GAE/100 $\mathrm{g}$ of honey using gallic acid standard (SingLETON et al., 1999).

\subsection{Microbial analysis}

Honey samples were aseptically streaked on nutrient agar and incubated. Also, the honey samples were aseptically serially diluted and the fourth, fifth, and sixth dilutions were plated on nutrient agar and rose Bengal chloramphenicol agar. The plates were then incubated for $48 \mathrm{~h}$. The microbial colonies were stained via Gram -staining technique and identified after performing biochemical tests (IMViC, oxidase, catalase) and plating in selective media 
(Eosin Methylene Blue agar, Mannitol Salt Agar, Cetrimide Agar and Mac Conkey Agar) (CAPPuCCINo \& SHERman, 2002).

\subsection{Antimicrobial analysis}

Clinical isolates of Escherichia coli, Pseudomonas aeruginosa, and Staphylococcus aureus were swabbed on Mueller Hinton Agar plates with wells of $6 \mathrm{~mm}$ diameter made using a gel cutter. Pure honey is aseptically introduced into the holes and incubated for $48 \mathrm{~h}$. Suitable antibiotics were also used as control. Diameters of zone of inhibition formed were noted in centimetres.

\section{Results and discussion}

\subsection{Organoleptic analysis}

The colour of the honey samples ranged between yellow to dark brown. Eleven samples smelled sweet and five samples gave an acrid odour (with a chemical tinge). All honey samples tasted sweet except for 3 samples. No honey was rejected at this stage. The results are given in Table 1.

Table 1. Results of organoleptic analysis of honey samples

\begin{tabular}{llll}
\hline Sample & Taste & Colour & Smell \\
\hline $\mathrm{M}_{1}$ & Sweet & Light brown & Sweet \\
$\mathrm{M}_{2}$ & Sweet & Dark brown & Sweet \\
$\mathrm{M}_{3}$ & Acrid & Dark brown & Sweet \\
$\mathrm{M}_{4}$ & Sweet & Golden yellow & Sweet \\
$\mathrm{M}_{5}$ & Acrid & Dark brown & Pungent \\
$\mathrm{M}_{6}$ & Sweet & Light brown & Sweet \\
$\mathrm{R}_{1}$ & Sweet & Yellow brown & Sweet \\
$\mathrm{R}_{2}$ & Acrid & Dark brown & Pungent \\
$\mathrm{R}_{3}$ & Acrid & Light brown & Pungent \\
$\mathrm{R}_{4}$ & Sweet & Dark brown & Sweet \\
$\mathrm{R}_{5}$ & Acrid & Golden yellow & Sweet \\
$\mathrm{R}_{6}$ & Sweet & Dark brown & Sweet \\
$\mathrm{I}_{1}$ & Sweet & Light brown & Sweet \\
$\mathrm{I}_{2}$ & Sweet & Dark brown & Sweet \\
$\mathrm{I}_{3}$ & Sweet & Light brown & Sweet \\
\hline
\end{tabular}

\subsection{Physicochemical analysis}

All honey samples had acceptable values of specific gravity with the least value of 1.302 for $\mathrm{I}_{3}$ and the highest value of 1.420 for $\mathrm{M}_{4}$. Most moisture values of all samples were in concordance to the set values of the BurEau of Indian Standards (BIS, 2002) with lowest of $22.6 \%$ shown by 2 samples. The moisture content of pure honey should be between $14 \%$ and 
$18 \%$, although this number depends heavily upon the season and geographical conditions, for good quality honey, it should be in the above range (UR-ReHman et al., 2008). High moisture values point towards developing fermentation.

Ash represents the direct measure of the inorganic residues after honey ashing. The ash value of honey is $0.2 \%$ for fresh and $1 \%$ on dry basis. The ash value decreases in cases of added sugar or water (MALIKA et al., 2005). The ash values obtained were in total agreement except for $\mathrm{R}_{2}$, which gave an ash value of $1 \%$.

All honey samples were of acidic $\mathrm{pH}$ with 2 honey samples, $\mathrm{R}_{1}$ and $\mathrm{R}_{2}$, going as low as 3.47 and 3.76, respectively. Likewise, all honey samples except $R_{2}$ were in agreement with the BIS standard value of acidity, i.e. $0.2 \%$ (formic acid, $w / w$ ). Total reducing sugar values were below the marked standards except for $\mathrm{M}_{6}$ and $\mathrm{R}_{5}$. However, the difference of reducing sugar values from the standards was not very big except for $R_{1}$ and $R_{3}$. Sucrose values of all honey samples exceeded the BIS standard value of $5 \%$. The values obtained were significant, implying the presence of added sucrose in the samples. $M_{1}$ gave a good value of 7.969 and $\mathrm{M}_{3}$ gave an alarming value of 31.83 (Table 2).

Table 2. Results of physicochemical analysis

\begin{tabular}{lcccccc}
\hline Sample & $\begin{array}{c}\text { Acidity } \\
\text { formic acid } \\
\%, \mathrm{w} / \mathrm{w})\end{array}$ & $\begin{array}{c}\text { Reducing } \\
\text { sugar } \\
\%(\mathrm{w} / \mathrm{w})\end{array}$ & $\begin{array}{c}\text { Sucrose } \\
\%(\mathrm{w} / \mathrm{w})\end{array}$ & $\begin{array}{c}\text { Specific } \\
\text { gravity at } \\
27^{\circ} \mathrm{C}\end{array}$ & $\begin{array}{c}\text { Moisture } \\
\%(\mathrm{w} / \mathrm{w})\end{array}$ & $\begin{array}{c}\text { Ash } \\
\%(\mathrm{w} / \mathrm{w})\end{array}$ \\
\hline BIS Values & 0.2 & 65 & 5 & 1.37 & 25 & 0.5 \\
$\mathrm{M}_{1}$ & 0.1288 & 63.04 & 7.969 & 1.415 & 23 & 0.16 \\
$\mathrm{M}_{2}$ & 0.1265 & 58.46 & 18.82 & 1.312 & 23.8 & 0.14 \\
$\mathrm{M}_{3}$ & 0.1495 & 60.41 & 31.83 & 1.388 & 22.6 & 0.17 \\
$\mathrm{M}_{4}$ & 0.1058 & 46.77 & 24.01 & 1.420 & 22.6 & 0.22 \\
$\mathrm{M}_{5}$ & 0.1495 & 60.41 & 27.33 & 1.380 & 26 & 0.14 \\
$\mathrm{M}_{6}$ & 0.1724 & 65.90 & 28.05 & 1.403 & 25.2 & 0.27 \\
$\mathrm{R}_{1}$ & 0.184 & 51.78 & 23.33 & 1.383 & 25 & 0.4 \\
$\mathrm{R}_{2}$ & 0.204 & 53.70 & 20.7 & 1.371 & 25.8 & 1 \\
$\mathrm{R}_{3}$ & 0.1541 & 51.78 & 26.19 & 1.377 & 26.2 & 0.26 \\
$\mathrm{R}_{4}$ & 0.12 & 63.04 & 14.5 & 1.401 & 23.8 & 0.3 \\
$\mathrm{R}_{5}$ & 0.0989 & 65.90 & 28.05 & 1.382 & 25.4 & 0.2 \\
$\mathrm{R}_{6}$ & 0.0736 & 59.18 & 21.32 & 1.369 & 25 & 0.4 \\
$\mathrm{I}_{1}$ & 0.1472 & 58 & 13.77 & 1.362 & 25.6 & 0.5 \\
$\mathrm{I}_{2}$ & 0.1495 & 61.44 & 14.13 & 1.355 & 24 & 0.16 \\
$\mathrm{I}_{3}$ & 0.161 & 57.53 & 12.87 & 1.302 & 25.2 & 0.3 \\
\hline
\end{tabular}

With these values in hand, honey samples $R_{1}, R_{2}$, and $M_{3}$ are subject to rejection. Physicochemical value variations from standards are indication of inadequate honey harvesting and management. Disparities may be addressed by developing targeted beekeeper education programs to improve honey harvesting, processing, and storing practices (SAHINLER et al., 2004). 


\subsection{Biochemical analysis}

About seven honey samples were tested negative for Fiehe's test (Fig. 1). However, a positive Fiehe's test (Fig. 2) is never a confirmed result of adulteration. A positive result can be the sign of aging, impurities during extraction, processing, or storage.

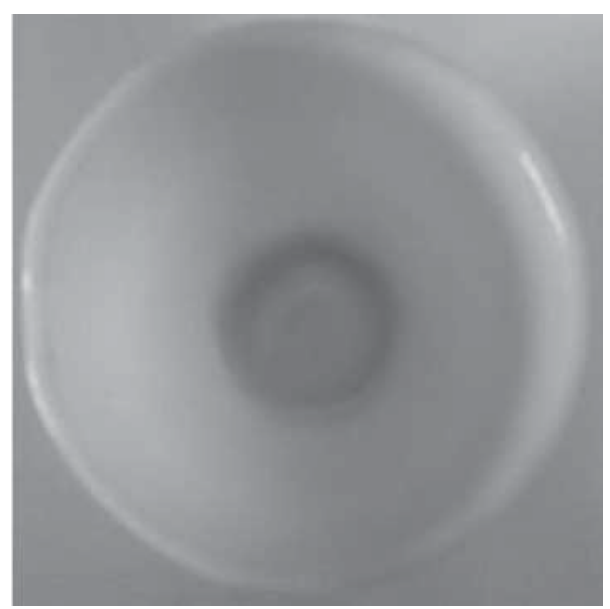

Fig. 1. Negative Fiehe's test

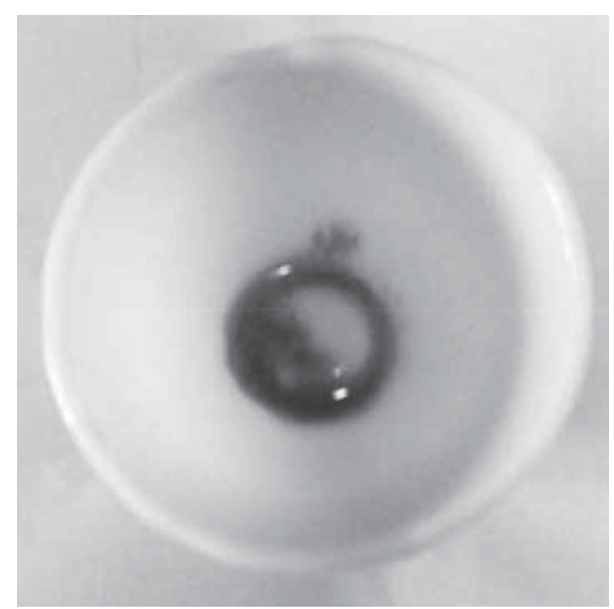

Fig. 2. Positive Fiehe's test

Table 3. Results of biochemical analysis of honey samples

\begin{tabular}{|c|c|c|c|}
\hline Sample & Fiehe's test & $\begin{array}{c}\mathrm{HMF} \\
\left(\mathrm{mg} \mathrm{kg}^{-1}\right)\end{array}$ & $\begin{array}{c}\text { Total phenol } \\
(\mathrm{mg} \mathrm{GAE} / 100 \mathrm{~g})\end{array}$ \\
\hline Standard values & - & 80 & 320 \\
\hline $\mathrm{M}_{1}$ & + & 36.48 & 420 \\
\hline $\mathrm{M}_{2}$ & - & 48 & 400 \\
\hline $\mathrm{M}_{3}$ & + & 42.24 & 580 \\
\hline $\mathrm{M}_{4}$ & - & 15.36 & 360 \\
\hline $\mathrm{M}_{5}$ & + & 165.12 & 510 \\
\hline $\mathrm{M}_{6}$ & - & 44.16 & 460 \\
\hline $\mathrm{R}_{1}$ & + & 153.16 & 360 \\
\hline $\mathrm{R}_{2}$ & + & 203.52 & 502 \\
\hline $\mathrm{R}_{3}$ & - & 15.36 & 417 \\
\hline $\mathrm{R}_{4}$ & - & 34.56 & 370 \\
\hline $\mathrm{R}_{5}$ & + & 107.52 & 367 \\
\hline $\mathrm{R}_{6}$ & - & 165.12 & 360 \\
\hline $\mathrm{I}_{1}$ & + & 49.92 & 372 \\
\hline $\mathrm{I}_{2}$ & + & 49.92 & 500 \\
\hline $\mathrm{I}_{3}$ & + & 11.52 & 356 \\
\hline
\end{tabular}

+: Positive; -: negative 
Upon HMF assay, it was seen that eleven honey samples were complied with the BIS standard value of $80 \mathrm{mg} \mathrm{HMF} / \mathrm{kg}$. The remaining five samples $\left(\mathrm{M}_{5}, \mathrm{R}_{1}, \mathrm{R}_{2}, \mathrm{R}_{5}\right.$, and $\left.\mathrm{R}_{6}\right)$ were immediately rejected as they had increased HMF content with $\mathrm{R}_{2}$ showing an alarming value of $203 \mathrm{mg} \mathrm{HMF} / \mathrm{kg}$ (Table 3).

Reasonably good values of total phenols (Table 3) were obtained for all honey samples, thereby highlighting the prominent antioxidant activity of honey. Higher antioxidant capacity was found for darker honey samples (Frankel et al., 1998; Chen et al., 2000; NAGAi et al., 2001; GHELDOF et al., 2002). Honey colour depends on the potential alkalinity and ash content, as well as on the antioxidatively active pigments, such as carotenoids and flavonoids (FrANKEL et al., 1998). This statement is truly in agreement with the results obtained, as honey samples that were noted to be dark brown in colour, like $\mathrm{M}_{5}, \mathrm{M}_{3}, \mathrm{R}_{2}$, and $\mathrm{I}_{2}$, in the organoleptic stage of analysis showed higher amounts of polyphenols.

\subsection{Microbial analysis}

Pure honey has been shown to be bactericidal to many pathogenic microorganisms including Salmonella spp., Shigella spp., other enteropathogens like Escherichia coli, Vibrio cholerae, and other Gram-negative and Gram-positive organism (SAHINLER et al., 2004). Likewise, in the present study, pure honey sample streaks showed no growth, signifying the inhibitory action of honey against microbes. The low $\mathrm{pH}$ and high sucrose content inhibit the growth of microbes. It was also observed that honey showed significant presence of microbial flora when serially diluted and plated. The distinguishable colonies obtained from nutrient agar plates were identified to be the following according to the biochemical tests (a) E. coli, (b) Enterobacter aerogenes, (c) Klebsiella pneumoniae, and (d) S. aureus.

Table 4. Microorganisms in honey samples

\begin{tabular}{lccccc}
\hline Sample & E. coli & S. aureus & K. pneumoniae & E. aerogenes & P. aeruginosa \\
\hline $\mathrm{M}_{1}$ & + & + & + & + & - \\
$\mathrm{M}_{2}$ & + & + & + & + & - \\
$\mathrm{M}_{3}$ & + & + & + & + & - \\
$\mathrm{M}_{4}$ & + & - & + & + & - \\
$\mathrm{M}_{5}$ & + & - & + & + & - \\
$\mathrm{M}_{6}$ & + & - & - & + & - \\
$\mathrm{R}_{1}$ & + & - & - & + & - \\
$\mathrm{R}_{2}$ & + & - & - & + & - \\
$\mathrm{R}_{3}$ & + & - & - & - & - \\
$\mathrm{R}_{4}$ & + & - & - & - & - \\
$\mathrm{R}_{5}$ & + & - & - & - & - \\
$\mathrm{R}_{6}$ & + & - & - & - & - \\
$\mathrm{I}_{1}$ & + & - & - & - & - \\
$\mathrm{I}_{2}$ & + & - & - & - & - \\
$\mathrm{I}_{3}$ & + & - & - & - & - \\
\hline
\end{tabular}


Table 5. Microbial counts in honey samples

\begin{tabular}{lcc}
\hline Sample & Bacterial count & Yeast count \\
\hline $\mathrm{M}_{1}$ & $23 \times 10^{5}$ & $15 \times 10^{6}$ \\
$\mathrm{M}_{2}$ & $9 \times 10^{5}$ & $6 \times 10^{6}$ \\
$\mathrm{M}_{3}$ & $20 \times 10^{5}$ & $3 \times 10^{6}$ \\
$\mathrm{M}_{4}$ & $21 \times 10^{5}$ & $3 \times 10^{6}$ \\
$\mathrm{M}_{5}$ & $21 \times 10^{5}$ & $3 \times 10^{6}$ \\
$\mathrm{M}_{6}$ & $19 \times 10^{5}$ & $2 \times 10^{6}$ \\
$\mathrm{R}_{1}$ & $37 \times 10^{5}$ & $1 \times 10^{6}$ \\
$\mathrm{R}_{2}$ & $40 \times 10^{5}$ & $2 \times 10^{6}$ \\
$\mathrm{R}_{3}$ & $39 \times 10^{5}$ & $11 \times 10^{6}$ \\
$\mathrm{R}_{4}$ & $14 \times 10^{5}$ & $1 \times 10^{6}$ \\
$\mathrm{R}_{5}$ & $20 \times 10^{5}$ & $14 \times 10^{6}$ \\
$\mathrm{R}_{6}$ & $19 \times 10^{5}$ & $2 \times 10^{6}$ \\
$\mathrm{I}_{1}$ & $30 \times 10^{5}$ & $10 \times 10^{6}$ \\
$\mathrm{I}_{2}$ & $20 \times 10^{5}$ & $1 \times 10^{6}$ \\
$\mathrm{I}_{3}$ & $27 \times 10^{5}$ & $11 \times 10^{6}$ \\
\hline
\end{tabular}

Culturing on Eosin Methylene Blue agar showed the presence of E. coli in all honey samples. Absence of growth in Cetrimide agar indicated the absence of $P$. aeruginosa in all samples (Table 4). Growth of E. aerogenes was noted in 8 samples, K. pneumoniae in 5 samples, and $S$. aureus in 3 samples. Due to high moisture levels, yeast colonies could be enumerated clearly from Rose Bengal Medium for the appropriate dilutions. Honey samples that showed high yeast counts include $M_{1}, R_{3}, R_{5}, I_{1}$, and $I_{3}$ (Table 5). Honey samples that showed slightly lower yeast cell count include $\mathrm{I}_{2}, \mathrm{R}_{1}$, and $\mathrm{R}_{4}$. Thus, control of moisture levels of honey can be critical in the maintenance of honey quality as yeasts cause undesirable fermentation.

\subsection{Antimicrobial analysis}

To study the antimicrobial activity in honey the gel diffusion method was applied. Honey samples showed variable degrees of inhibition against the cultures swabbed. Pure honey acted best against Pseudomonas aeruginosa (Figs 3, 4). Honey sample that showed good antimicrobial activity against all three studied bacteria was $\mathrm{I}_{3}$ (Table 6).

Table 6. Inhibition zones (in $\mathrm{cm}$ ) of honey samples

\begin{tabular}{lccc}
\hline Sample & E. coli & S. aureus & P. aeruginosa \\
\hline $\mathrm{M}_{1}$ & - & - & 1 \\
$\mathrm{M}_{2}$ & - & 1.2 & 0.8 \\
$\mathrm{M}_{3}$ & - & 1.4 & 1 \\
$\mathrm{M}_{4}$ & - & 1.2 & 1.3 \\
$\mathrm{M}_{5}$ & - & - & 0.6 \\
\hline
\end{tabular}


Table 6. Continued

\begin{tabular}{lccc}
\hline Sample & E. coli & S. aureus & P. aeruginosa \\
\hline $\mathrm{M}_{6}$ & - & - & 0.8 \\
$\mathrm{R}_{1}$ & - & - & 1.2 \\
$\mathrm{R}_{2}$ & - & 1 & 1 \\
$\mathrm{R}_{3}$ & - & 1 & 1 \\
$\mathrm{R}_{4}$ & - & 0.8 & - \\
$\mathrm{R}_{5}$ & - & - & 1 \\
$\mathrm{R}_{6}$ & - & 1 & 1.2 \\
$\mathrm{I}_{1}$ & 1.5 & - & 1.2 \\
$\mathrm{I}_{2}$ & 1 & 1.4 & - \\
$\mathrm{I}_{3}$ & 1.2 & 1 & 1.2 \\
Gentamycin & 1.2 & 2.3 & 1.6 \\
Amoxycillin & - & 0.7 & - \\
\hline
\end{tabular}

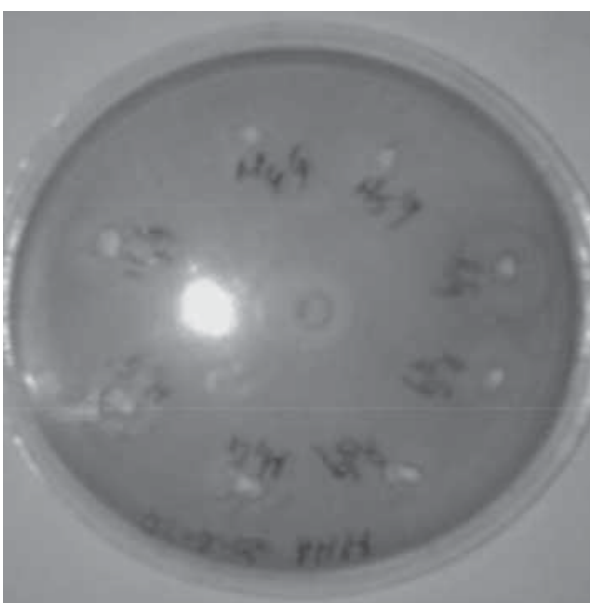

Fig. 3. Antibiogram of $P$. aeruginosa

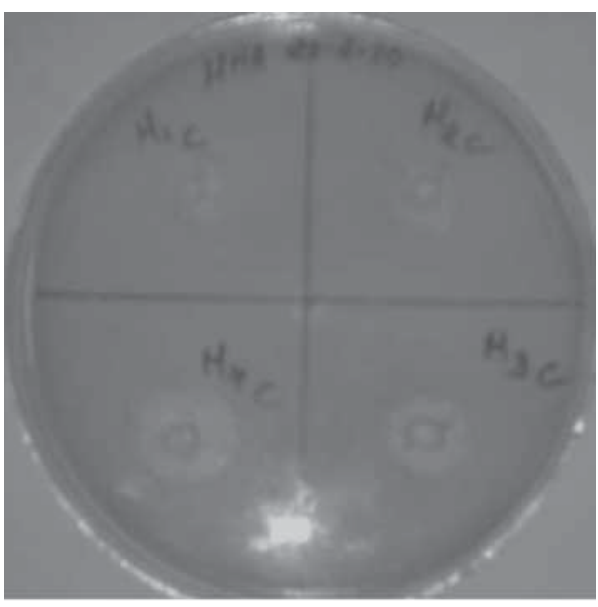

Fig. 4. Antibiogram of S. aureus

\section{Conclusions}

No honey samples showed near to ideal characteristics of the BIS standards. Physicochemical value variations are indicative of inadequate honey harvesting and management that needs to be urgently tackled. All honey samples were found to have proper amounts of polyphenols as well as exhibited variable antimicrobial abilities. The high sucrose content and $\mathrm{pH}$ significantly contribute to the honey's antimicrobial property observed for the pure honey streaks and confirmed in the antimicrobial assay. However, the microbial flora was observed to emerge when the sucrose is diluted and $\mathrm{pH}$ is raised. Honey fermentation due to increased levels of osmophilic yeasts results in loss of palatability and product souring. This can be checked by maintaining moisture levels by clean storage of honey in dehumidifiers 
after pasteurizing practices. Less than $10 \mathrm{CFU} \mathrm{ml}^{-1}$ yeast cells is the acceptable microbiological standard for honey usage at industrial level.

\section{List of abbreviations:}

CFU: colony forming unit; GAE: gallic acid equivalents; IMViC test: Indole Methyl Red Voges Proskauer Citrate Test; 5-HMF: 5-Hydroxymethyl furfural

Our sincere acknowledgments to Dr. N. Prabhu I.F.S., Managing Director, Oushadhi and K. Sasidharan, Administrative Officer, Oushadhi for permitting and providing all facilities in Oushadhi, Kutanellur for the sincere completion of this work. We sincerely thank Dr. V.V. Pyarelal, Director, K.V.M. Trust for providing the necessary support. We wish to thank Dr. K.N. James, Principal, K.V.M. College of Engineering \& IT for constant inspiration during the course of this study.

\section{References}

A.O.A.C. (1984): Official method of analysis. Association of Official Analytical Chemists $13^{\text {th }}$ ed., Washington DC, USA.

BIS (2002): Specifications for extracted honey. $2^{\text {nd }}$ revision. Bureau of Indian Standard IS 4941:1994.

Cappuccino, J.G. \& Sherman, N. (2002): Microbiology: Laboratory manual, $5^{\text {th }}$ ed., Benjamin Cumming Publishing Co., California, USA, pp. 152-187.

Chen, L., Mehta, A., Berenbaum, M., Zangerl, A.R. \& Engeseth, N.J. (2000): Honeys from different floral sources as inhibitors of enzymatic browning in fruit and vegetable homogenates. J. Agric. Fd Chem., 48, 4997-5000.

Codex Alimentarius Commission (2001): Revised Codex Standard for Honey, Codex STAN 12-1981; Rev. 1 (1987); Rev. 2 (2001); FAO/WHO, 215.

EfEm, S.E. (1988): Clinical observations on wound healing properties of honey. British J. Surg., 75, 679-681.

Frankel, S., Robinson, G.E.\& Berenbaum, M.R. (1998): Antioxidant capacity and correlated characteristics of 14 unifloral honeys. J. Api. Res., 37, 27-31.

Gheldof, N.\&Engeseth, N.J. (2002): Antioxidant capacity of honeys from various floral sources based on the determination of oxygen radical absorbance capacity and inhibition of in vitro lipoprotein oxidation in human serum samples. J. Agric. Fd Chem., 50, 3050-3055.

Gheldof, N., Wang, X.H.\&Engeseth, N.J. (2002): Identification and quantification of antioxidant components of honeys from various floral sources. J. Agric. Fd Chem., 50, 5870-5877.

KaČaniová, M., Melich, M., Kňazovická, V., Haščik, P., Sudzinová, J., Pavličová, S.\&Čuboň, J. (2009): The indicator microorganisms value in relation to primary contamination of honey. Lucrări stiintifice Zootehnie şi Biotehnologii, 42, 159-163.

Malika, N., Mohamed, F.\& ChakiB, E. (2005): Microbiological and physico-chemical properties of Moroccan honey. Int. J. Agr. Biol., 7, 773-776.

Nagai, T., Sakai, M., Inoue, R., Inoue, H.\&Suzuki, N. (2001): Antioxidative activities of some commercially honeys, royal jelly, and propolis. Fd Chem., 75, 237-240.

Olaitan, P.B., Adeleke, O.E.\& Ola, I.O. (2007): Honey: a reservoir for microorganisms and an inhibitory agent for microbes. Afr. Health Sci., 7, 159-165.

Sahinler, N., SuAt, S.\&Aziz, G. (2004): Biochemical compositions of honey produced in Turkey. J. Api. Res., 43, 53-56.

Singleton, V.L., Orthofer, R. \& Lamuela-Raventos, R.M. (1999): Analysis of total phenols and other oxidation substrates and antioxidants by means of Folin-Ciocalteu reagent. Methods Enzymol., 299, 152-178.

Snowdon, J.A. \& Cliver, D.O. (1996): Microorganisms in honey. Int. J. Fd Microbiol., 31, 1-26.

Tchoumboue, J., Awah-Ndukum, J., Fonteh, F.A., Dongock, N.D., Pinta, J.\& Mvondo, Z.A. (2007): Physicochemical and microbiological characteristics of honey from the Sudano-Guinean zone of West Cameroon. Afr. J. Biotechnol., 6, 908-913.

Ur-Rehman, S., Farooq Khan, Z.\& Maqbool, T. (2008): Physical and spectroscopic characterization of Pakistani honey. Cien. Inv. Agr., 35, 199-204.

Vit, P., Sancho, T., Pascual, A.\&Deliza, R. (2011): Sensory perception of tropical pot honeys by Spanish consumers, using free choice profile. J. ApiProduct ApiMed. Sci., 3, 174-180. 